\title{
PENERAPAN MODEL PENGEMBANGAN GAMEGDLC (GAME DEVELOPMENT LIFE CYCLE DALAM MEMBANGUN GAME PLATFORM BERBASIS MOBILE
}

\author{
Rio Andriyat Krisdiawan ${ }^{1}$, Darsanto ${ }^{2}$ \\ ${ }^{I}$ Fakultas Ilmu Komputer Universitas Kuningan \\ ${ }^{2}$ Teknik Komputer Universitas Wiralodra \\ Irioandriyat@uniku.com / rioandriyat@uniku.ac.id \\ 2aziz.faiz310105@gmail.com/ shanto.ft@unwir.ac.id
}

\begin{abstract}
ABSTRAK
Permainan atau yang sering disebut games merupakan salah satu aktivitas yang sering dilakukan oleh kebanyakan orang dalam mencari hiburan dan kesenangan. Perkembangan games dari masa kemasa semakin beragam jenis dan aktivitasnya. Mulai dari games tradisonal yang dilakukan secara konvensional sampai dengan games yang dilakukan dengan teknologi.Dilihat dari perkembangan teknologi, games bukan lagi sebagai aktivitas yang sulit untuk dimainkan, games dapat dimainkan dimana saja melalui perangkat teknologi apapun.Perkembangan games selain dari teknologi, juga sangat berkembang dari segi jenis/genre dari games itu sendiri, yang menyesuaikan dengan kebutuhan pengguna/player. Berbagai genre game pun muncul, seperti genre action, adventure, $R P G$, simulasi, strategi dan lainnya.Pada penelitian kali ini peneliti berfokus kepada subgenre games action yaitu platform games. Beberapa platform games yang terkenal yaitu Mario bros, Jumping Flash, Donkey Kong. Games yang ringan tetapi memiliki unsur kesenangan dan menantang bagi yang memainkannya. Peneliti merasa tertarik dalam meneliti bagaimana membangun sebuah game platform dengan teknik pengembangan game GDLC (Game Development Life Cycle), dengan model perancangan game menggunakan model UML(Unifield Modeling Language). Game yang akan dikembangkan yaitu game platform yang merupakan subgenre dari genre actiongames yang dapat dijalankan pada perangkat mobile phone berbasis android.
\end{abstract}

Kata Kunci : Games Platform, GDLC, UML.

\begin{abstract}
Games or often called games are one of the activities that are often carried out by most people in seeking entertainment and pleasure. The development of games from time to time increasingly diverse types and activities. Starting from traditional games carried out in a conventional manner to games made with technology. Viewed from technological developments, games are no longer an activity that is difficult to play, games can be played anywhere through any technological device. The development of games apart from technology, is also very developed in terms of types / genres from the games themselves, which adjust to the needs of users / players. Various game genres also appear, such as the genre of action, adventure, RPG, simulation, strategy and others. In this study the researchers focused on action games subgenre, platform games. Some well-known platform games are Mario Bros, Jumping Flash, Donkey Kong. Games are lightweight but have elements of fun and challenge for those who play them. Researchers feel interested in researching how to build a game platform with GDLC game development techniques (Game Development Life Cycle), with the game design model using the UML (Unifield Modeling Language) model. The game that will be developed is a platform game which is a subgenre of the action games genre that can be run on an Android-based mobile phone.
\end{abstract}

Keywords: Games Platform, GDLC, UML 


\section{PENDAHULUAN}

Permainan atau yang sering disebut games merupakan salah satu aktivitas yang sering dilakukan oleh kebanyakan orang dalam mencari hiburan dan kesenangan. Perkembangan games dari masa kemasa semakin beragam jenis dan aktivitasnya. Mulai dari games tradisonal yang dilakukan secara konvensional sampai dengan games yang dilakukan dengan teknologi. Teknologi dalam permainan sangatlah beragam, mulai dengan teknologi sederhana, sampai teknologi yang sangat kompleks.

Dilihat dari perkembangan teknologi, games bukan lagi sebagai aktivitas yang sulit untuk dimainkan, games dapat dimainkan dimana saja melalui perangkat teknologi apapun. Hal tersebut tidak terlepas dari perkembangan teknologi yang memungkinkan berbagai macam game dapat dimainkan dalam berbagai platform system operasi. Mulai dari games yang dapat dimainkan di perangkat Komputer, Handphone, MobilePhone, Xbox, Console dan lainnya.

Perkembangan games selain dari teknologi, juga sangat berkembang dari segi jenis/genre dari games itu sendiri, yang menyesuaikan dengan kebutuhan pengguna/player. Berbagai genre game pun muncul, seperti genre action, adventure, $R P G$, simulasi, strategi dan lainnya. Dari genre tersebut masih dapat dikelompokan ke berbagai jenis subgenre seperti halnya game action; yaitu game yang menampilkan aksi laga yang penuh dengan adegan baku tembak, menghindari rintangan yang memerlukan konsentrasi untuk mencapai point tertinggi. Subgenre dari game action seperti platform games, shooter games, fighting games, survival games.

Pada penelitian kali ini peneliti berfokus kepada subgenre games action yaitu platform games. Beberapa platform games yang terkenal yaitu Mario bros, Jumping Flash, Donkey Kong. Games yang ringan tetapi memiliki unsur kesenangan dan menantang bagi yang memainkannya. Menghindari rintangan, melawan musuh, dan mencapai skor tertinggi dari permainan tersebut.

Dalam membangun game yang sangat menarik seperti itu pastinya pengembang game/game development memiliki tahapan sendiri dalam membuat dan mengembangkannya, sehingga player dapat terus menerus tertarik dan selalu memaikan game tersebut. Tidak bisa dipungkiri, games platform sampai dengan saat ini masih banyak digemari dan dimainkan oleh berbagai kalangan, karena unsur game tersebut tidak mengenal batasa usia untuk dimainkan.

Peneliti merasa tertarik dalam meneliti bagaimana membangun sebuah game platform dengan teknik pengembangan game GDLC (Game Development Life Cycle). GDLC adalah suatu proses pengembangan sebuah game yang menerapkan pendekatan iteratifyang terdiri dari 6 fase pengembangan, dimulai dari fase inisialisasi/pembuatan konsep, preproduction, production, testing, beta dan realease. Dari 6 fase tersebut dapat dikelompokkan menjadi 3 proses utama yaitu; Proses Inisialisasi yang terdiri dari konsep dan design, Proses produksi terdiri dari Pra Produksi, Produksi, dan Pengujian (Alpha dan Beta), dan Realease.

Untuk model perancangan game pada penelitian ini penulis menggunakan model UML(Unifield Modeling Language); yaitu suatu pemodelan desain yang menerapkan pemrograman berorientasi objek (OOP) didalamnya. Game yang akan dikembangkan yaitu game platform yang merupakan subgenre dari genre actiongames yang dapat dijalankan pada perangkat mobile phone berbasis android.

Dari latarbelakang diatas, peneliti merumuskan permasalahan dalam penelitian ini sebagai berikut:

1. Bagaimana Menerapkan model pengembangan gameGDLC dalam membangun Game Platform.

2. Bagaimana tahapan GDLC dalam menentukan pembuatan game yang menarik dan menyenangkan.

3. Bagaimana merancang sebuah game platform dengan model perancangan sistem berbasis $U M L$.

Maksud dari penelitian ini adalah untuk menerapkan proses pengembangan game platform dengan menggunakanmodel pengembangan yang sesuai, yaitu Game Development Life Cycle (GDLC).

Tujuan dari penelitian ini adalah untuk merancang dan membangun sebuah game platform 2D yang menarik dan menyenangkan bagi pengguna. 


\section{METODELOGI PENELITIAN}

\section{A. Metode Pengembangan Game}

Metodologi pengembangan game yang digunakan oleh penulis dalam melakukan penelitian ini adalah Game Development Life Cycle (GDLC).

Metode pengembangan sistem yang digunakan dalam perancangan aplikasi perangkat lunak ini menggunakan metodologi kerja GDLC (Game Development Life Cycle). GDLC adalah suatu proses pengembangan sebuahgame yang menerapkan pendekatan iteratifyang terdiri dari 6 fase pengembangan,dimulai dari fase inisialisasi/pembuatan konsep, preproduction, production, testing, beta dan realease. Dari 6 fase tersebut dapat dikelompokkan menjadi 3 proses utama yaitu:

a. Proses Inisialisasi yang terdiri dari konsep dan design.

b. Proses produksi terdiri dari Pra Produksi, Produksi, dan Pengujian (Alpha dan Beta).

c. Realease

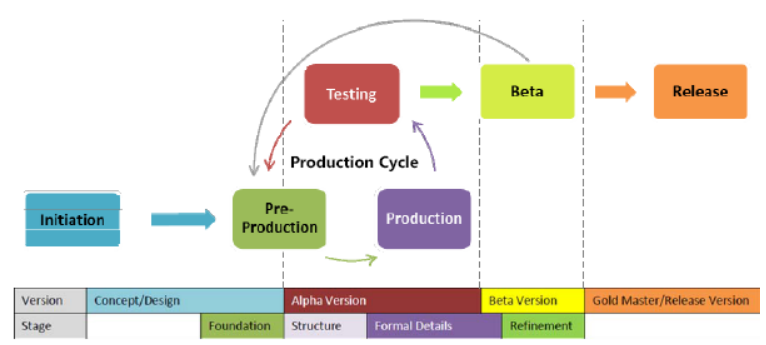

Gambar 1. Fase dan Proses GDLC

\section{B. Penjelasan Fase dan Proses GDLC:}

\section{Initiation (Inisiasi)}

"Adalah proses awal yang berupa pembuatan konsep kasar dari game, mulai dari menentukan game seperti apa yang akan dibuat, mulai dari indentifikasi dari trending, topik, , target user dari game yang akan dibuat. Output dari tahap initation adalah konsep game dan deskripsi permainan yang sangat sederhana".

Pada tahap ini peneliti akanmembuat sebuah konsep game yang akan dibangun, berupa analisa akan seperti apa game itu dibangun, initiation akan menghasilkan konsep game dan deskripsi sederhana game. Pada initiation akan menjabarkan tentang scenario game, karakter, cerita dalam game, target pemain, platform yang digunakan dan game engine.

a. Jenis permainan yang dibuat

b. Game skenario

c. Game karakter

d. Story game

e. Target user/pengguna

f. Platform gameyang digunakan

\section{Pra-Production}

"Pra-produksi adalah salah satu fase yang penting dalam siklus produksi. Praproduksi melibatkan penciptaan dan revisi desain game dan pembuatan prototipe permainan. Desain game berfokus pada mendefinisikan genre permainan, gameplay, game mekanik/konfensional, alur cerita, karakter, tantangan, faktor kesenangan, aspek teknis, dan dokumentasi elemennya dalam Dokumen Desain Game (GDD).

Pra-produksi berakhir ketika revisi atau perubahan desain game telah disetujui dan didokumentasikan di GDD"

Pada tahap Pra-production peneliti akan melakukan pengumpulan data dengan cara mencari referensi, yang berkaitan dengan game yang akan dibuat, seperti:

a) Genre yang akan di pakai pada gameini yaitu game platform.

b) Sekenario game berupa pegunungan, karakter pada game yaitu pokemon, enemy berupa semut, landak dan pokemon ball sebagai peluru untuk weapon pokemon.

c) Scenario game player berupa pokemon berpetualangan menghindari enemy, dan mengumpulkan pokemon ball sebagai senjata untuk melawan enemy. Player menjelajahi rintangan sambal mengumpulkan koin gold sebagai point.

d) Target pemain pada game ini yaitu masyarakat umum.

e) Peneliti menggunakan game egineConstruct $2 D$ dan menggunakan Corel dan Photoshop untuk membuat aset yang akan di terapkan pada game. 


\section{Production}

"Produksi adalah proses inti yang berputar di sekitar penciptaan aset, pembuatan kode sumber, dan integrasi kedua elemen. Prototipe terkait dalam fase ini adalah perincian dan penyempurnaan formal".

Gamedesign dan prototype dan point lainnya yang ada pada pre-productionyang disempurnakan pada tahap ini. Artinya pada tahap ini penulis memiliki fokus pada menerjemahkan rancangan mengumpulkan data, desain game, membuat sekenario permainan, membuat aset untuk karakter player maupun enemy, pepohonan, makanan player dalam game, dan aspek - aspek lainnya menjadi unsur penyusun game. Tahap ini mencakup assetcreation, programming dan integration antara asset dan sourcecode.

\section{Pengujian}

"Pengujian dalam konteks ini berarti pengujian internal dan eksternal dilakukan untuk menguji kegunaan permainan. Metode pengujian khusus untuk setiap tahap prototype".

a) Alpha Testing

Setelah melakukan produksi, Pengujian ini dilakukanpeneliti untuk melakukan pengecekan apakah masih ada bug atau tidak dan akan ada kemungkinan pengurangan atau penambahan feature. Jika ada bug/eror dan penambahan feature maka peneliti akan memperbaikinya.

b) Beta Testing

Setelah game selesai dibuat, belum berarti game tersebut akan diterima oleh masyarakat. Peneliti akan melakulanEksternaltesting, dikenal dengan istilah betatestingakan dilakukan oleh peneliti untuk menguji keberterimaan game dan untuk mendeteksi berbagai error dan keluhan yang dilemparkan oleh thirdpartytester. Beta berada diluar productioncycle, tetapi jika hasil dari testing ini berpotensi masih ada eror maka peneliti akan mengulangi productioncycle.

\section{Release}

Jika Game yang sudah selesai dibuat dan lulus betatesting menandakan game tersebut maka peneliti sudah siap untuk dirilis.

\section{Model Perancangan $U M L$}

"Unified Modelling Language (UML) adalah keluarga notasi grafis yang didukung oleh model-model tunggal, yang membantu pendeskripsian dan desain sistem perangkat lunak, khususnya sistem yang dibangun menggunakan pemrograman berorientasi objek".(Martin Fowler,2004).

UML adalah sekumpulan alat yang digunakan untuk melakukan abstraksi terhadap sebuah sistem atau perangkat lunak berbasis objek. UML juga menjadi salah satu cara untuk mempermudah pengembangan aplikasi yang berkelanjutan. Aplikasi atau sistem yang tidak terdokumentasi biasanya dapat menghambat pengembangan karena developer harus melakukan penelusuran dan mempelajari kode program. UML juga dapat menjadi alat bantu untuk transfer ilmu tentang sistem atau aplikasi yang akan dikembangkan dari satu developer ke developer lainya. Tidak hanya antar developer terhadap orang bisnis dan siapapun dapat memahami sebuah sistem dengan adanya UML.

UML diciptakan oleh Object Management Group yang diawali dengan versi 1.0 pada Januari 1997. Dalam pengembangan berorientasi objek ada beberapa prinsip yang harus dikenal:
a. Object
b. Class
c. Abstraction
d. Encapsulation
e. Inheritance
f. Polymorphism.

Dengan menggunakan $U M L$ kita dapat membuat model untuk semua jenis aplikasi piranti lunak, dimana aplikasi tersebut dapat berjalan pada piranti keras, sistem operasi dan jaringan apapun, serta ditulis dalam bahasa pemrograman apapun. Tetapi karena $U M L$ juga menggunakan class dan operation dalam konsep dasarnya, maka ia lebih cocok untuk penulisan piranti lunak dalam bahasa-bahasa berorientasi objek seperti $\mathrm{C}++$, Java, C\# atau VB.NET. Walaupun demikian, $U M L$ tetap dapat digunakan untuk modeling aplikasi prosedural dalam VB atau C.

Seperti bahasa-bahasa lainnya, $U M L$ mendefinisikan notasi dan syntax/semantik. Notasi $U M L$ merupakan sekumpulan bentuk khusus untuk menggambarkan berbagai 
diagram piranti lunak. Setiap bentuk memiliki makna tertentu, dan UML syntax mendefinisikan bagaimana bentuk-bentuk tersebut dapat dikombinasikan. Notasi $U M L$ terutama diturunkan dari 3 notasi yang telah ada sebelumnya: Grady Booch OOD (ObjectOriented Design), Jim Rumbaugh OMT (Object Modeling Technique), dan Ivar Jacobson OOSE (Object-Oriented Software Engineering).

Menurut Rosa A.S dan Salahuddin, UML terdiri dari 13 macam diagram yang dikelompokkan dalam 3 kategori. Pembagian kategori dan macam macam diagram tersebut dapat dilihat pada gambar di bawah ini.

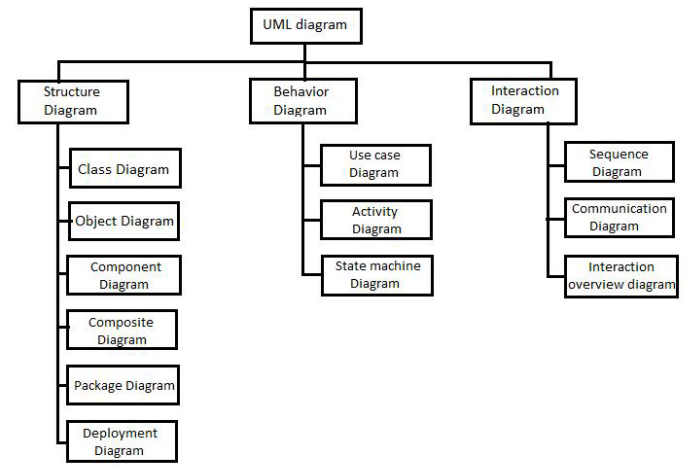

Gambar 2. Macam-macam Diagram UML

Pemodelan yang akan digunakan oleh peneliti pada penelitian ini yaitu; Usecase diagram, Activity Diagram, class diagram dan sequence diagram.

\section{HASIL DAN PEMBAHASAN}

\section{A. GamePlay}

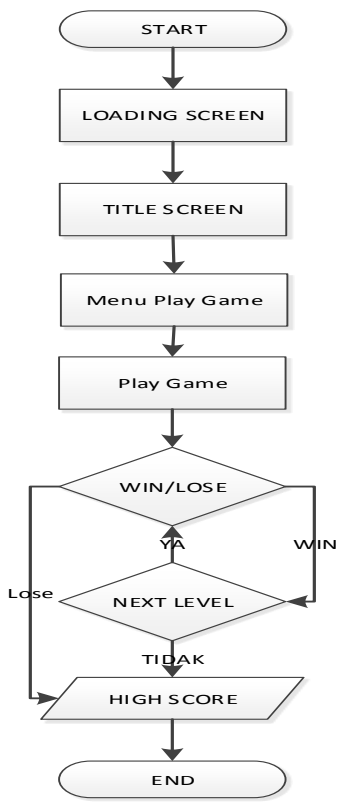

Gambar 3. GamePlay Pika Adventure

\section{B. Perancangan Use Case Diagram}

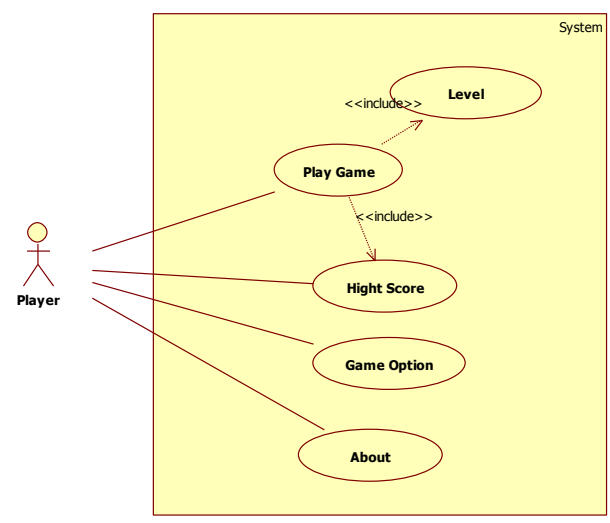

Gambar 4.Use case diagram Game

Pada gambar 4use case diagram akan di deskripsikan sebagai berikut :

a. Skenario Use Case Play Game

Tabel 1. Deskripsi Use CasePlay Game

\begin{tabular}{|c|c|c|}
\hline $\begin{array}{l}\text { Nama } \\
\text { Use Case }\end{array}$ & \multicolumn{2}{|l|}{ Play Game } \\
\hline Aktor & \multicolumn{2}{|l|}{ Player } \\
\hline Deskripsi & \multicolumn{2}{|c|}{$\begin{array}{l}\text { Proses Ini adalah player akan } \\
\text { memainkan game. }\end{array}$} \\
\hline \multirow[t]{4}{*}{ Kondisi } & Player & Game \\
\hline & $\begin{array}{l}\text { 1.Memilih } \\
\text { menu Play. }\end{array}$ & $\begin{array}{l}\text { 2.Mengecek Lock } \\
\text { Level }\end{array}$ \\
\hline & $\begin{array}{l}\text { 3. Memilih } \\
\text { level }\end{array}$ & $\begin{array}{l}\text { 4. Menampilkan } \\
\text { level }\end{array}$ \\
\hline & $\begin{array}{l}\text { 5. Memainkan } \\
\text { Game sesuai } \\
\text { level }\end{array}$ & $\begin{array}{l}\text { 6. Menampilkan } \\
\text { layout game } \\
\text { sesuai level yang } \\
\text { dipilih }\end{array}$ \\
\hline $\begin{array}{l}\text { Pre- } \\
\text { Condition }\end{array}$ & \multicolumn{2}{|c|}{ Player Memainkan Permainan } \\
\hline $\begin{array}{l}\text { Post- } \\
\text { Condition }\end{array}$ & \multicolumn{2}{|c|}{$\begin{array}{l}\text { Player Memilih tipe Permainan dan } \\
\text { Level sebelum bermain }\end{array}$} \\
\hline
\end{tabular}

b. Skenario Use CaseHight Score

Tabel 2. Deskripsi Use CaseHight Score

\begin{tabular}{|c|c|c|}
\hline $\begin{array}{l}\text { Nama } \\
\text { Use Case }\end{array}$ & \multicolumn{2}{|l|}{ Hight Score } \\
\hline Aktor & \multicolumn{2}{|l|}{ Player } \\
\hline Deskripsi & \multicolumn{2}{|c|}{ Melihat Hight Score } \\
\hline Kondisi & Player & Game \\
\hline & $\begin{array}{l}\text { Player memilih } \\
\text { Hight Score }\end{array}$ & $\begin{array}{l}\text { Menampilkan } \\
\text { Hight Score }\end{array}$ \\
\hline $\begin{array}{l}\text { Pre- } \\
\text { Condition }\end{array}$ & \multicolumn{2}{|c|}{ Player Memilih menu Hight Score } \\
\hline $\begin{array}{l}\text { Post- } \\
\text { Condition }\end{array}$ & \multicolumn{2}{|c|}{ Player dapat melihat Hight Score } \\
\hline
\end{tabular}


c. Skenario Use Case Game Option Tabel 3. Deskripsi Use CaseGame Option

\begin{tabular}{|l|l|l|}
\hline $\begin{array}{l}\text { Nama } \\
\text { Use Case }\end{array}$ & \multicolumn{3}{|l|}{ Game Option } \\
\hline Aktor & \multicolumn{2}{|l|}{ Player } \\
\hline Deskripsi & Melihat menu game option. \\
\hline Kondisi & \multicolumn{1}{|c|}{ Player } & \multicolumn{1}{c|}{ Game } \\
\hline & $\begin{array}{l}\text { Player memilih } \\
\text { Game Option }\end{array}$ & $\begin{array}{l}\text { Menampilkan } \\
\text { Game Option }\end{array}$ \\
\hline $\begin{array}{l}\text { Pre- } \\
\text { Condition }\end{array}$ & $\begin{array}{l}\text { Player Memilih } \\
\text { Option }\end{array}$ \\
\hline $\begin{array}{l}\text { Post- } \\
\text { Condition }\end{array}$ & $\begin{array}{l}\text { Player dapat melihat option game } \\
\text { control }\end{array}$ \\
\hline
\end{tabular}

\section{Activity Diagram}

Diagram activity akan menampilkan aliran kerja atau aktivitas dari sebuah sistem yang ada pada aplikasi game. Di mana aktivitas ini akan menggambarkan aktivitas game dan bukan yang di lakukan oleh aktor terhadap aplikasi, jadi activity diagram ini akan menampilkan aktivitas-aktivitas yang dilakukan oleh system.

a. Activity Diagram Play Game

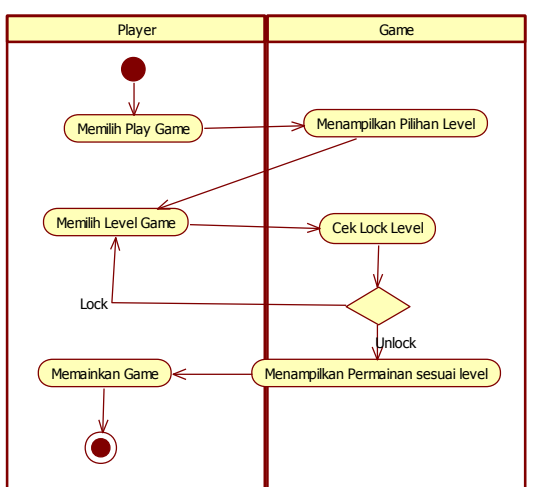

Gambar 5.Activity diagram Play Game

b. Activity Diagram Hight Score

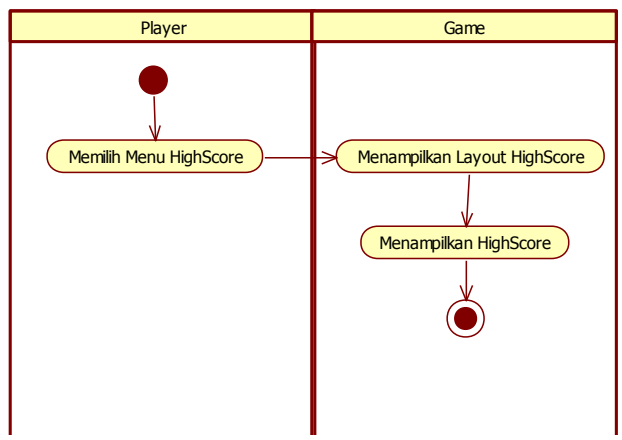

Gambar 6.Activity diagram Hight Score c. Activity Diagram Game Option

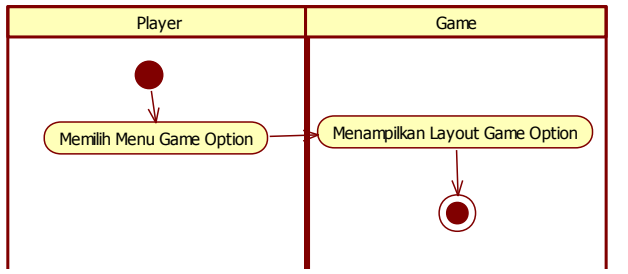

Gambar 7.Activity diagram Game Option

D. Sequence Diagram

a. Sequence Diagram Play Game

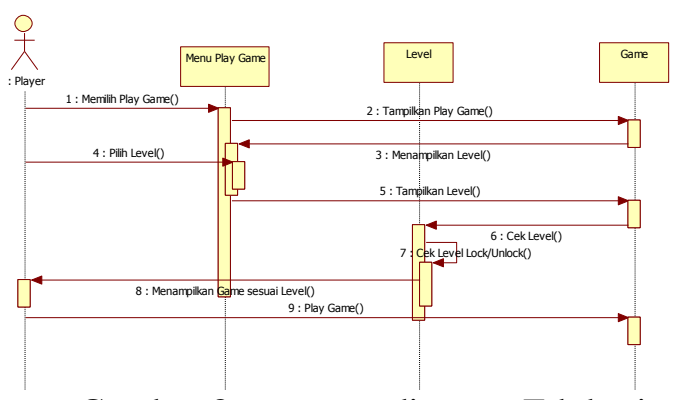

Gambar 8.sequence diagram Edukasi

\section{b. Sequence Diagram Hight Score}

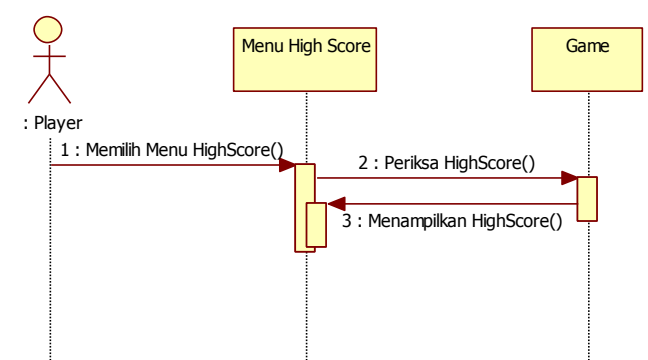

Gambar 9. Sequence diagram Hight Score

c. Sequence Diagram Game Option

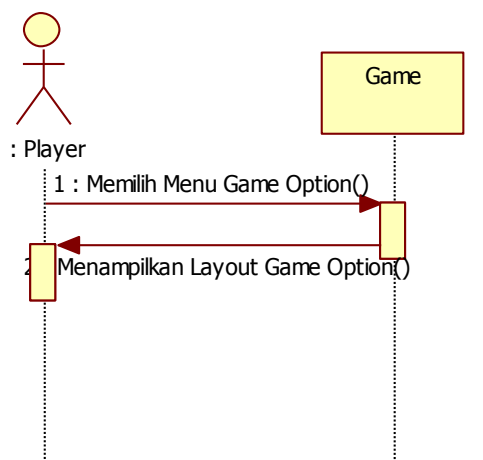

Gambar 10. Sequence diagram Game Option 


\section{E. Class Diagram}

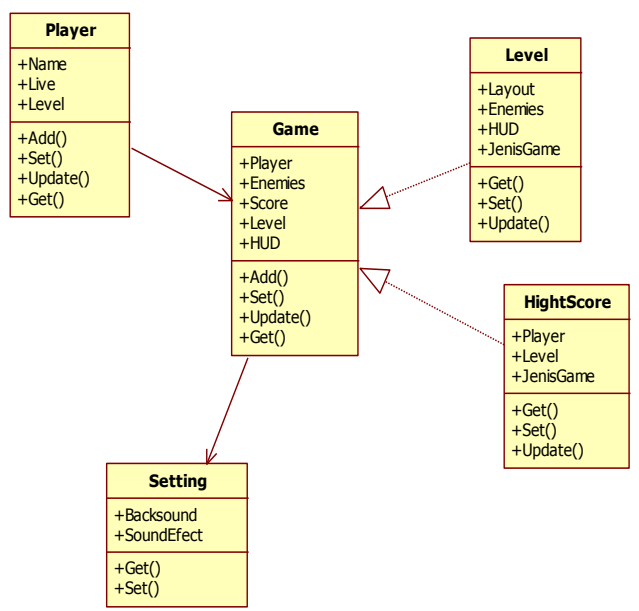

Gambar 11.Class diagram Game

\section{F. Production}

Produksi adalah proses inti yang berputar di sekitar penciptaan aset, pembuatan kode sumber, dan integrasi kedua elemen. Prototipe terkait dalam fase ini adalah perincian dan penyempurnaan formal. Hasil dari game yang sudah dibuat dapat dilihat pada tampilan Gambar berikut :

\section{Tampilan Play Game}

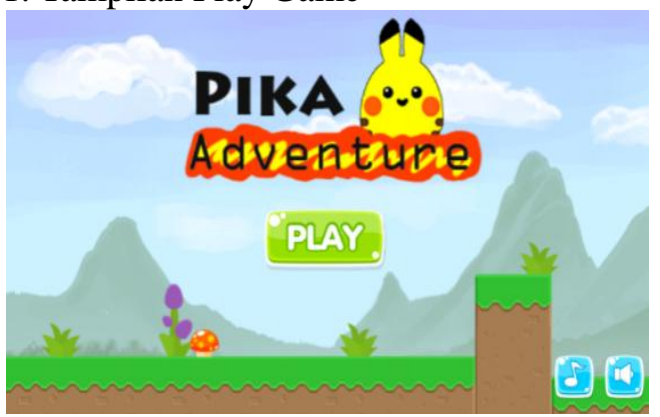

Gambar 12. Tampilan Play Game

2. Tampilan Level

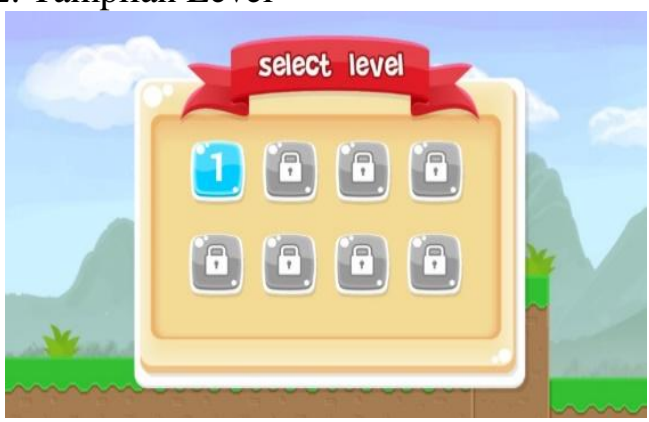

Gambar 13. Tampilan Level.
3. TampilanPlay Game

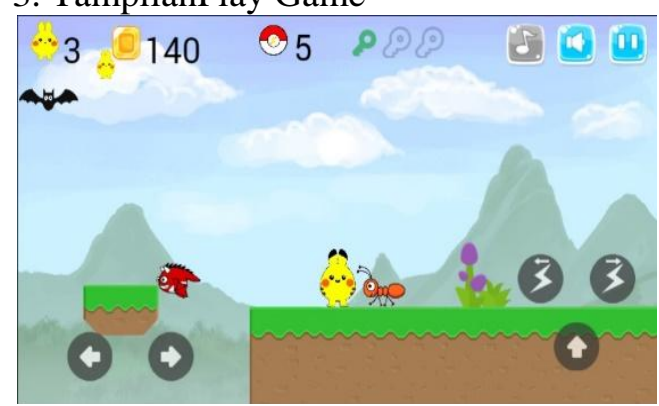

Gambar 14. Halaman Play Game

\section{Tampilan Game Over}

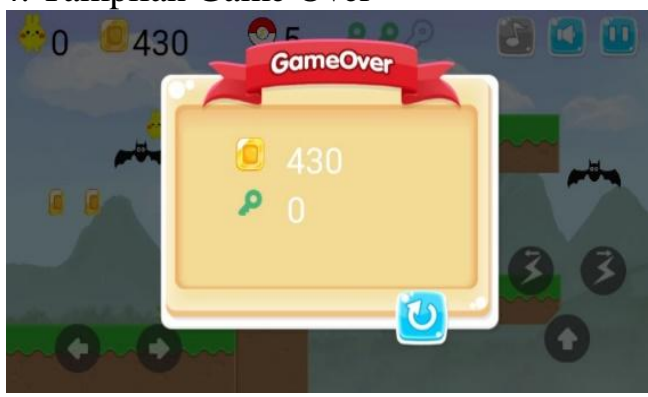

Gambar 15. Halaman Game Over

\section{Tampilan Victory Condition}

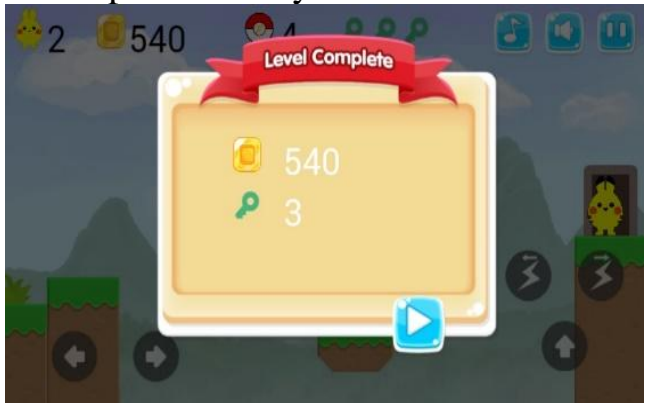

Gambar 16. Halaman Victory Condition

\section{G. Pengujian}

Pengujian dalam konteks ini berarti pengujian internal dan eksternal dilakukan untuk menguji kegunaan permainan. Metode pengujian khusus untuk setiap tahap prototype

1. Alpha Testing

Setelah melakukan produksi, Pengujian ini dilakukanpeneliti untuk melakukan pengecekan apakah masih ada bug atau tidak dan akan ada kemungkinan pengurangan atau penambahan feature. Jika ada bug/eror dan penambahan feature maka peneliti akan memperbaikinya.

a. Pengujian Black Box 
Tabel 4.Hasil Pengujian Black Box

\begin{tabular}{|l|l|l|l|l|}
\hline No & $\begin{array}{l}\text { Fungsi } \\
\text { yang } \\
\text { di uji }\end{array}$ & $\begin{array}{l}\text { Cara } \\
\text { Menguji }\end{array}$ & $\begin{array}{l}\text { Hasil } \\
\text { yang } \\
\text { diharapk } \\
\text { an }\end{array}$ & $\begin{array}{l}\text { Hasil } \\
\text { yang } \\
\text { keluar }\end{array}$ \\
\hline 1 & $\begin{array}{l}\text { Play } \\
\text { Game }\end{array}$ & $\begin{array}{l}\text { Memilih } \\
\text { menu } \\
\text { playgame }\end{array}$ & $\begin{array}{l}\text { Playgam } \\
\text { e dapat } \\
\text { diakses } \\
\text { dan layot } \\
\text { playgam } \\
\text { e dapat } \\
\text { diakses }\end{array}$ & $\begin{array}{l}\text { Sesuai } \\
\text { dengan } \\
\text { harapan } \\
\text { Valid }\end{array}$ \\
\hline 2 & $\begin{array}{l}\text { Cek } \\
\text { Menu }\end{array}$ & $\begin{array}{l}\text { Memilih } \\
\text { semua } \\
\text { menu pada } \\
\text { game }\end{array}$ & $\begin{array}{l}\text { Semua } \\
\text { layout } \\
\text { dapat } \\
\text { diakses }\end{array}$ & $\begin{array}{l}\text { Sesuai } \\
\text { dengan } \\
\text { harapan } \\
\text { Valid }\end{array}$ \\
\hline 3. & Level & $\begin{array}{l}\text { Mengakses } \\
\text { Level }\end{array}$ & $\begin{array}{l}\text { Level } \\
\text { hanya } \\
\text { bias } \\
\text { diakses } \\
\text { jika } \\
\text { terbuka }\end{array}$ & $\begin{array}{l}\text { Sesuai } \\
\text { dengan } \\
\text { harapan } \\
\text { Valid }\end{array}$ \\
\hline
\end{tabular}

\section{2. $\quad$ Beta Testing}

Setelah game selesai dibuat, belum berarti game tersebut akan diterima oleh masyarakat. Peneliti akan melakulanEksternaltesting, dikenal dengan istilah betatestingakan dilakukan oleh peneliti untuk menguji keberterimaan game dan untuk mendeteksi berbagai error dan keluhan yang dilemparkan oleh thirdpartytester. Beta berada diluar productioncycle, tetapi jika hasil dari testing ini berpotensi masih ada eror makapeneliti akan mengulangi productioncycle lagi.

a. Pengujian UAT (User Acceptance Test)

Pengujian UATyang dilakukan penulis berlangsung di lingkungan user dan melibatkan beberapa pengujian ekstensif oleh sekelompok user.

Untuk mengetahui tanggapan user terhadap game yang dibangun, maka dilakukan pengujian dengan memberikan 4 pertanyaan kepada 20 user dimana jawaban dari pertanyaan tersebut terdiri dari tingkatan yang dapat dipilih sebagai berikut:

Tabel 5 Komponen Pilihan Jawaban responden

\begin{tabular}{|c|l|}
\hline A & Sangat : Mudah/Bagus/Sesuai/Jelas \\
\hline B & Mudah/Bagus/Sesuai/Jelas \\
\hline
\end{tabular}

\begin{tabular}{|c|l|}
\hline C & Netral \\
\hline D & Cukup : Sulit/Bagus/Sesuai/Jelas \\
\hline E & Sangat : Sulit/Jelek/Tidak Sesuai/Tidak Jelas \\
\hline
\end{tabular}

Tabel 6 Komponen Bobot Nilai responden

\begin{tabular}{|l|c|}
\hline \multicolumn{1}{|c|}{ Jawaban } & Bobot \\
\hline A. Sangat : Mudah/Bagus/Sesuai/Jelas & 5 \\
\hline B. Mudah/Bagus/Sesuai/Jelas & 4 \\
\hline C. Netral & 3 \\
\hline D. Cukup : Sulit/Bagus/Sesuai/Jelas & 2 \\
\hline $\begin{array}{l}\text { E. Sangat : Sulit/Jelek/Tidak } \\
\text { Sesuai/Tidak Jelas }\end{array}$ & 1 \\
\hline
\end{tabular}

Tabel 7 Pertanyaan Quesioner

\begin{tabular}{|c|c|c|c|c|c|c|}
\hline $\begin{array}{c}\mathbf{N} \\
\mathbf{0}\end{array}$ & Pertanyaan & $\mathbf{A}$ & B & $\mathbf{C}$ & D & $\mathbf{E}$ \\
\hline 1 & $\begin{array}{l}\text { Apakah Tampilan UI (User } \\
\text { Interface) game ini } \\
\text { menarik? }\end{array}$ & & & & & \\
\hline 2 & $\begin{array}{lr}\text { Apakah game } & \text { sangat } \\
\text { menantang } & \\
\text { dimainkan? } & \text { untuk } \\
\end{array}$ & & & & & \\
\hline 3 & $\begin{array}{l}\text { Apakah objek dalam game } \\
\text { tersebut sesuai dengan tema } \\
\text { game? }\end{array}$ & & & & & \\
\hline 4 & $\begin{array}{lcr}\text { Apakah } & \text { game } & \text { dapat } \\
\text { dijalankan } & \text { di } & \text { platform } \\
\text { android? } & & \end{array}$ & & & & & \\
\hline 5 & $\begin{array}{l}\text { Apakah control game mudah } \\
\text { untuk dikendalikan? }\end{array}$ & & & & & \\
\hline
\end{tabular}

Tabel 8 Data Jawaban Quesioner

\begin{tabular}{|c|c|c|c|c|c|c|c|c|c|c|c|}
\hline \multirow{2}{*}{$\begin{array}{l}\mathbf{N} \\
\mathbf{O}\end{array}$} & \multirow{2}{*}{ Pertanyaan } & \multicolumn{5}{|c|}{ Jawaban } & \multicolumn{5}{|c|}{ Persentase } \\
\hline & & $\mathbf{A}$ & B & C & D & $\mathbf{E}$ & $\mathbf{A}$ & B & C & D & $\mathbf{E}$ \\
\hline 1 & $\begin{array}{l}\text { Apakah } \\
\text { Tampilan UI } \\
\text { (User } \\
\text { Interface) } \\
\text { game ini } \\
\text { menarik? }\end{array}$ & 15 & 3 & 2 & 1 & & $\begin{array}{l}75 \\
\%\end{array}$ & $\begin{array}{l}15 \\
\%\end{array}$ & $\begin{array}{l}10 \\
\%\end{array}$ & $\begin{array}{l}5 \\
\%\end{array}$ & $\begin{array}{c}0 \\
\%\end{array}$ \\
\hline 2 & $\begin{array}{l}\text { Apakah game } \\
\text { sangat } \\
\text { menantang } \\
\text { untuk } \\
\text { dimainkan? }\end{array}$ & 10 & 5 & 3 & 2 & 1 & $\begin{array}{l}50 \\
\%\end{array}$ & $\begin{array}{l}25 \\
\%\end{array}$ & $\begin{array}{l}15 \\
\%\end{array}$ & $\begin{array}{l}10 \\
\%\end{array}$ & $\begin{array}{c}5 \\
\%\end{array}$ \\
\hline 3 & $\begin{array}{l}\text { Apakah objek } \\
\text { dalam game } \\
\text { tersebut } \\
\text { sesuai dengan } \\
\text { tema game? }\end{array}$ & 10 & 6 & 3 & 1 & & $\begin{array}{l}50 \\
\%\end{array}$ & $\begin{array}{l}30 \\
\%\end{array}$ & $\begin{array}{l}15 \\
\%\end{array}$ & $\begin{array}{c}5 \\
\%\end{array}$ & $\begin{array}{c}0 \\
\%\end{array}$ \\
\hline 4 & $\begin{array}{l}\text { Apakah game } \\
\text { dapat } \\
\text { dijalankan di } \\
\text { platform } \\
\text { android? }\end{array}$ & 8 & 8 & 2 & 2 & 1 & $\begin{array}{l}40 \\
\%\end{array}$ & $\begin{array}{l}40 \\
\%\end{array}$ & $\begin{array}{l}10 \\
\%\end{array}$ & $\begin{array}{l}10 \\
\%\end{array}$ & $\begin{array}{l}5 \\
\%\end{array}$ \\
\hline 5 & $\begin{array}{l}\text { Apakah } \\
\text { control game } \\
\text { mudah untuk } \\
\text { dikendalikan? }\end{array}$ & 10 & 3 & 3 & 2 & 2 & $\begin{array}{l}50 \\
\%\end{array}$ & $\begin{array}{l}15 \\
\%\end{array}$ & $\begin{array}{l}15 \\
\%\end{array}$ & $\begin{array}{l}10 \\
\%\end{array}$ & $\begin{array}{l}10 \\
\%\end{array}$ \\
\hline
\end{tabular}


Data yang didapat di atas diolah dengan cara mengalikan setiap poin jawaban dengan bobot yang sudah ditentukan sesuai dengan tabel bobot nilai jawaban.

Tabel 9 Data Kuesioner Setelah Diolah

\begin{tabular}{|c|c|c|c|c|c|c|c|c|c|}
\hline \multirow{2}{*}{$\begin{array}{l}\mathbf{N} \\
\mathbf{O}\end{array}$} & \multirow{2}{*}{ Pertanyaan } & \multicolumn{5}{|c|}{ Nilai } & \multirow[t]{2}{*}{ jml } & \multirow[t]{2}{*}{ NR } & \multirow[t]{2}{*}{$\begin{array}{c}\text { NR } \\
\% \\
\end{array}$} \\
\hline & & 5 & 4 & 3 & 2 & 1 & & & \\
\hline 1 & $\begin{array}{l}\text { Apakah } \\
\text { Tampilan UI } \\
\text { (User Interface) } \\
\text { game } \\
\text { menarik? }\end{array}$ & 75 & 12 & 6 & 2 & 0 & 95 & 4,75 & 95 \\
\hline 2 & $\begin{array}{l}\text { Apakah game } \\
\text { sangat } \\
\text { menantang untuk } \\
\text { dimainkan? }\end{array}$ & 50 & 20 & 9 & 4 & 1 & 84 & 4,2 & 84 \\
\hline 3 & $\begin{array}{lr}\text { Apakah } & \text { objek } \\
\text { dalam } & \text { game } \\
\text { tersebut } & \text { sesuai } \\
\text { dengan } & \text { tema } \\
\text { game? } & \\
\end{array}$ & 50 & 24 & 9 & 2 & 0 & 85 & 4,25 & 85 \\
\hline 4 & $\begin{array}{l}\text { Apakah game } \\
\text { dapat dijalankan } \\
\text { di platform } \\
\text { android? }\end{array}$ & 40 & 32 & 6 & 4 & 1 & 83 & 4,15 & 83 \\
\hline 5 & $\begin{array}{l}\text { Apakah control } \\
\text { game mudah } \\
\text { untuk } \\
\text { dikendalikan? }\end{array}$ & 50 & 12 & 9 & 4 & 2 & 77 & 3,85 & 77 \\
\hline
\end{tabular}

Ket :

$N R=$ Nilai Rata-rata $($ Jumlah / Responden $)$ $N R \%=$ Persentase $($ NR/Point Tertinggi $x$ 100)

Dari data diatas dapat disimpulkan bahwa game tersebut memiliki Tampilan UI (User Interface)yang menarik, sangat menantang, sesuai dengan tema dan dapat dijalankan di platform android dengan control yang mudah.

\section{KESIMPULAN}

Berdasarkan hasil penerapan dan pembahasan yang telah dilakukan, maka dapat ditarik kesimpulan sebagai berikut.

1. GDLC sangat cocok digunakan dalam mengembangkan pembuatan game.

2. GDLC berperan dalam game development team dalam membangun game.

3. Model Prancangan $U M L$ memberikan kemudahan perancangan system untuk pemrograman $O O P$ seperti perancangan game.

4. Pengujian game sangat cocok jika menerapkan model pengujian alfa dan beta testing seperti yang dibahas.

\section{DAFTAR PUSTAKA}

[1]. Fowler, Martin.UML Distiled: Panduan Singkat Bahasa Pemodelan Object Standar, Edisi 3, Penerbit Andi: Yogyakarta. 2004.

[2]. https://usersnap.com/blog/useracceptance-testing-right : Matthew Setter

[3]. Krisdiawan, R. A. (2018). Implementasi Model Pengembangan Sistem Gdlc Dan Algoritma Linear Congruential Generator Pada Game Puzzle. Nuansa Informatika, 12(2).

[4]. Pressman, Roger S. (2007). Rekayasa Perangkat Lunak: pendekatan praktisi (Buku1). Beizer, B. (1995). Black-Box Testing, Wiley. Yogyakarta: Andi

[5]. Ramadan Rido and Yani Widyani; Game Development Life Cycle Guid; ICACSIS 2013 ISBN: 978-979-142119-5; September 2013.

[6]. Rosa AS dan M.Shalahuddin. 2015. Rekayasa Perangkat Lunak Terstruktur Dan Berorientasi Objek. Bandung : INFORMATIKA 
Halaman ini sengaja dikosongkan 